\title{
Distribution of major diseases of shallot in South Kalimantan, Indonesia
}

\author{
YUNIEKA AULIA SAFITRI ${ }^{1}$, USWATUN HASANAH ${ }^{2}$, SALAMIAH $^{1, \boldsymbol{v}}$, SAMHARINTO $^{1}$, \\ M. INDAR PRAMUDI ${ }^{1}$ \\ ${ }^{1}$ Department of Plant Protection, Faculty of Agriculture, Universitas Lambung Mangkurat. Jl. Jend. A. Yani Km. 36, Banjarbaru 70714, South \\ Kalimantan, Indonesia. Tel./fax.: +62-477-72254, `email: salamiah@ulm.ac.id \\ ${ }^{2}$ Department of Agrotechnology, Faculty of Agriculture, Universitas Lambung Mangkurat. Jl. Jend. A. Yani Km. 36, Banjarbaru 70714, South \\ Kalimantan, Indonesia
}

Manuscript received: 9 December 2018. Revision accepted: 4 June 2019.

\begin{abstract}
Safitri YA, Hasanah U, Salamiah, Samharinto, Pramudi MI. 2019. Distribution of major diseases of shallot in South Kalimantan, Indonesia. Asian J Agric 3: 33-40. Shallot is a vegetable crop with high economic value, but its productivity in Indonesia is still relatively low. One of the causes is due to diseases. The research was conducted from November 2017 to April 2018 , with the purpose of studying the distribution of major diseases of shallots in South Kalimantan. It consisted of field, laboratory, and greenhouse research. Field research included the survey of shallots' extensive planting in eight villages of six districts in South Kalimantan, disease symptoms, the broad of attack, and the collection of secondary data. Laboratory research included the isolation and identification of the pathogen causing diseases. The greenhouse research was conducted to perform the Postulate Koch test. The research results showed that there were two major diseases of shallots, namely Moler and Anthracnose. Pathogen causing Moler disease (Fusarium oxysporum) attacked shallot plants in six districts (Tabalong, Balangan, Tanah Laut, Kotabaru, Tapin, and Banjarbaru) and pathogen causing Anthracnose disease (Colletotrichum sp) attacked shallot plants in five districts (Tabalong, Balangan, Tanah Laut, Kotabaru, and Tapin).
\end{abstract}

Keywords: Anthracnose, distribution of disease, Moler, shallots

\section{INTRODUCTION}

Shallot (Allium ascalonicum) is one of the vegetable commodities that has a high economic value with a diverse utility from the household to industrial scale. This commodity is needed year-round. Therefore, when the stock is low but the demand is high, the prices increase and sometimes can affect national inflation. This can happen outside of the growing season, especially at the beginning of the rainy season. To solve this problem, the government has the policy to expand production by planting outside the planting season, not only centralized in Java and lowland, but also in South Kalimantan, Indonesia. The obstacle of planting shallots outside the planting season, especially in rainy season, is the risk of disease.

Shallot has been developed in South Kalimantan since 2013 and was initially developed in only two districts. The two districts were Tapin District (5 ha) and Tanah Laut (3 ha). Then in 2015, it was further developed in 8 districts, i.e., Tanah Laut, Tapin, Hulu Sungai Selatan, Hulu Sungai Tengah, Tanah Bumbu, Balangan, Tabalong, and Banjarbaru with a total land area of 148 ha. Whereas in 2017, shallot planting was expanded to 10 districts from 13 districts in South Kalimantan with an area of 422 ha. But Hulu Sungai Tengah did not take part in this program, and was replaced with Hulu Sungai Utara, Kotabaru and Barito Kuala. The average shallot productivity in South Kalimantan is between 5-12 t.ha ${ }^{-1}$. Based on the annual report in 2014-2018 by Dinas Pertanian South Kalimantan report that the main types of pathogens that attack shallot in
South Kalimantan are Fusarium, Anthracnose and Purple blotch.

According to Udiarto et al. (2005), the loss resulting from diseased shallots could reach 24-100 \%. The effectiveness in controlling plant disease is determined by the information accuracy of infecting pathogen types, factors affecting reproduction, and factors helping the spread of diseases. Fusarium wilt disease is a disease attacking the onion plants either in the growing season or out of season (the rainy season) and can reduce crop yields to $27-75 \%$ (Adiyoga et al. 2000). According to Bambang and Khusnul (2014), anthracnose can reduce crop yields ranging from $21-63 \%$ even to $100 \%$ if conditions support especially when wet, heavy rain, and humid. Porch blotch of onion caused by Alternaria porri is an important disease of onion worldwide (Glande and Simon 2019). The disease yields a loss of 30\% (Everts and Lacy 1990).

Hence, the information about the spread of disease in South Kalimantan is needed as the starting data point. The spread of plant diseases will determine accurate control measures. Therefore, this research was conducted to gain information about the distribution of major diseases to create a distribution map.

\section{MATERIALS AND METHODS}

The research was conducted in districts of Tabalong, Balangan, Tapin, Tanah Laut, Kotabaru, and Banjarbaru of 
South Kalimantan, Indonesia from November 2017 to April 2018. The sample of infected plants and the soil surrounding them were collected for disease isolation and identification in a laboratory. The laboratory research was in the form of the pathogen reproduction or the cultural reproduction of pathogen causing the disease. This consisted of stages such as isolation, purification, and identification of the pathogens. Furthermore, the postulate Koch test was performed in the greenhouse.

\section{Major diseases isolation and identification}

The media used for the disease isolation and identification were Potato Dextrose Agar (PDA) and Nutrient Agar (NA) (Tuite 1969). The infected shallots were isolated and purified in the reproduction media. Meanwhile, the soil taken from around the roots of infected plants was weighed as much as $10 \mathrm{~g}$ and put in the glass bottle containing sterile distilled water about $90 \mathrm{ml}$. Then, they were homogenized for 15 minutes in an orbital shaker with a speed of $150 \mathrm{rpm}$ and were diluted to $10^{-6}$ to observe the shape of spores and hyphae of fungi needed in the Contrast phase microscope ML 2000. The identification of the diseases was based on key identification literature for pathogens (Barnett 1960; Booth 1971; Alexopoulos dan Mims 1978; Agrios 1996).

\section{Koch Postulate test}

The Koch Postulate test was conducted to gain an accurate result of disease identification. Isolated and purified culture of the pathogen was cultured in the reproduction media. The pure culture pathogen obtained from previous isolation in the laboratory were then inoculated to healthy shallots aged 15 days after planting. Inoculation was done by spraying and flushing the suspension of Fusarium oxysporum fungi and Colletotrichum sp. fungi as much as $10 \mathrm{ml}$ with each spore density of $3 \times 107$ conidia.ml ${ }^{-1}$. The observation was conducted every day until the symptoms appeared on shallots. The plants showing the symptoms were then isolated again to create a pure isolate. The pathogen isolate was observed under the microscope to find out whether the morphology of isolated pathogens was like the inoculated pathogens. The identified pathogens were clarified by comparison of similarity of both conditions.

\section{Mapping of major diseases in South Kalimantan}

Mapping preparation activity consisted of collecting toponym data and analyzing the major diseases of shallots in South Kalimantan. The supporting data collected included the maps of Tabalong, Balangan, Tapin, Tanah Laut, Kotabaru, and Banjarbaru districts. The map of Indonesian toponym or Rupa Bumi Indonesia (RBI) was taken from Ina-Geoportal, a web of Indonesian geospatial agencies owning geospatial data including RBI map. Secondary data was collected through a questionnaire by interviewing farmers about the area of onion planting, when the land was first planted with shallots, a disease that had attacked the plant, and how the control was carried out.
The field observation comprised the symptom elements of major diseases of shallots in chosen areas. The symptom observations were carried out in plant areas in each district in South Kalimantan. The coordinates were determined using GPS to find out the site coordinates where the major diseases attacked shallots. The observation parameters for observing the large of the major disease attack on shallots in South Kalimantan used the formula:

$$
\text { Percentage of the large of attack }=\frac{\text { Plant area under attack }}{\text { Total plant area }} \times 100 \%
$$

The map of research results referred to the data gained from the field. All the areas, whether spatial or attribute, were digitized into GIS application. In this case, ArcGIS was used for processing data spatially. With the help of GIS analysis, the distribution map of major diseases affecting shallots in South Kalimantan was made. Next, the field observations were inputted as coordinate points and the data analysis of major diseases was put in Global Mapper application to convert the file format from .gpx for GPS into .shp that could be read by ArcGIS application. The converted file was put in ArcGIS application. The results comprised of the map and description of major diseases distribution on shallots in districts/cities in South Kalimantan.

\section{RESULTS AND DISCUSSION}

According to the results of field observations from six districts in South Kalimantan, there were two types of symptoms that attacked shallots in South Kalimantan, namely the symptoms of Moler and Anthracnose.

\section{Disease identification}

Moler symptom disease caused by Fusarium oxysporum fungi and had isolate characteristics as presented in Table 1. The morphology of the colony and the shape of conidium is shown in Figure 1.

Table 1. The characteristics of Fusarium oxysporum fungi on shallot plants

\begin{tabular}{|c|c|}
\hline Characteristics & Description \\
\hline $\begin{array}{l}\text { The part which the symptoms are } \\
\text { visible (the part of shallots plant) }\end{array}$ & $\begin{array}{l}\text { Whole parts of leaf } \\
\text { (rolled) }\end{array}$ \\
\hline The color of colony & Pale white-yellowish \\
\hline $\begin{array}{l}\text { The diameter of colony ( } 4^{\text {th }} \text { day) in } \\
\text { PDA medium }\end{array}$ & $\pm 4.63 \mathrm{~mm}$ \\
\hline The color of spores & Pale white \\
\hline The shape of hyphae & Insulate \\
\hline The shape of mycelium & Cotton-like \\
\hline \multicolumn{2}{|l|}{ Microconidia } \\
\hline - Shape & Oval \\
\hline - The number of septa & 0 septa \\
\hline \multicolumn{2}{|l|}{ Macroconidia } \\
\hline - Shape & Crescent moon-like \\
\hline - The number of septa & 3-5 septa \\
\hline
\end{tabular}




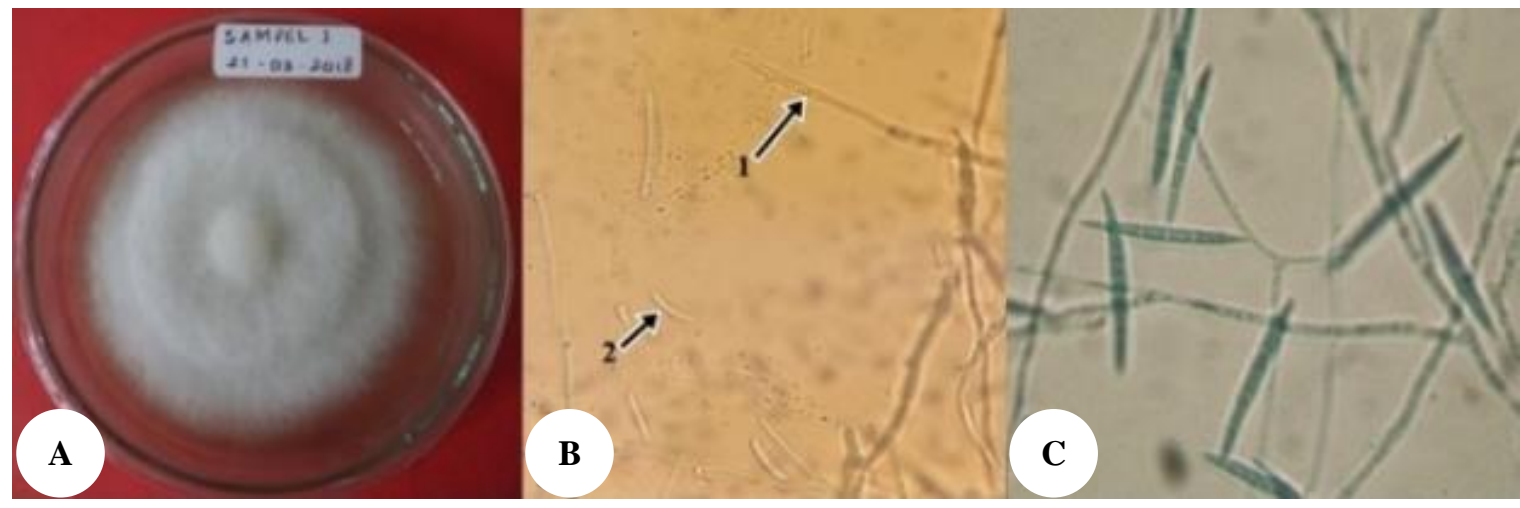

Figure 1. Fusarium oxysporum on shallots. A. The Morphology of colony $8^{\text {th }}$ day on PDA medium, B. Hyphae, and Microconidia (1 and 2); C. Macroconidia under the contrast phase microscope ML 2000 (400x magnification)
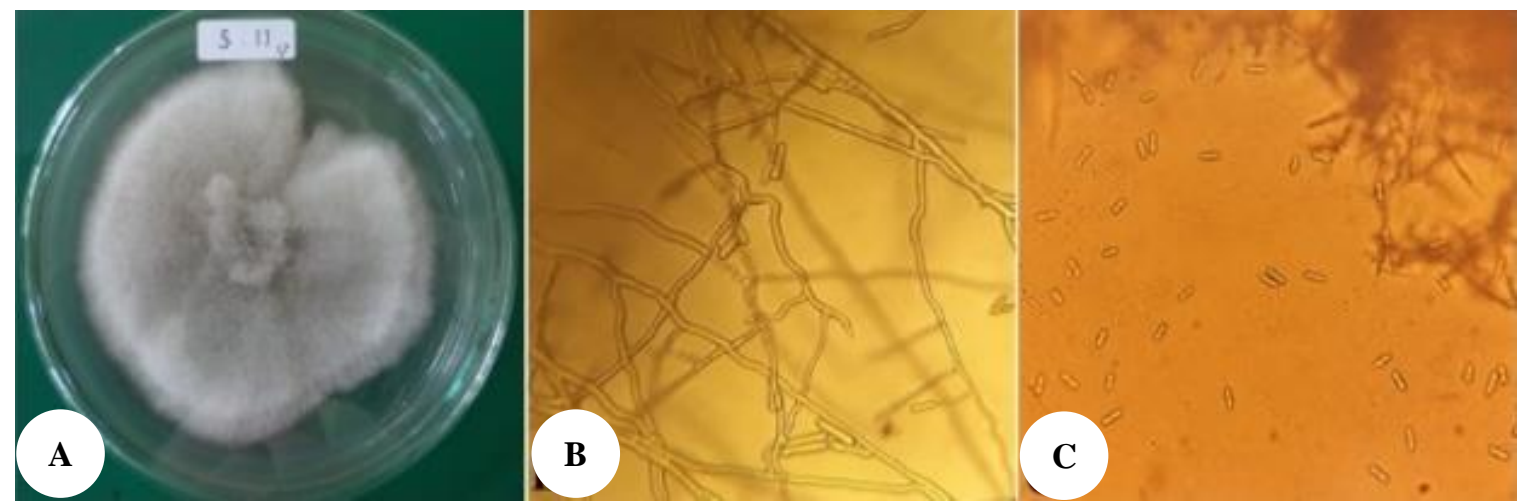

Figure 2. Colletotrichum sp. on a shallot plant. A. The morphology of colony on media PDA medium at $8^{\text {th }}$ day of observation, B. Hyphae, C. Conidia under the Contrast phase microscope ML 2000 (400x magnification)

Table 2. The characteristics of Colletotrichum sp. fungi on shallots plants

\begin{tabular}{ll}
\hline Characteristics & Colletotrichum $\mathbf{s p .}$ \\
\hline $\begin{array}{l}\text { The part which the symptoms are visible } \\
\text { (the part of shallots plant) }\end{array}$ & $\begin{array}{l}\text { Part of leaf } \\
\text { (spotted) }\end{array}$ \\
$\begin{array}{l}\text { The color of colony } \\
\text { The diameter of colony ( } 4^{\text {th }} \text { day) in PDA }\end{array}$ & $\begin{array}{l}\text { Gray blackish } \\
\pm 4,74 \mathrm{~cm}\end{array}$ \\
medium & \\
The color of spore & Pale white \\
The shape of hyphae & No insulate \\
The shape of mycelium & Cotton-like \\
Conidia shape & Tube-like \\
\hline
\end{tabular}

Another symptom in shallot plants was Anthracnose disease, caused by Colletotrichum sp. fungi. In the medium of Potato Dextrose Agar (PDA), Colletotrichum sp. fungi could grow well at room temperature. The fungi attached to shallots had the isolate characteristics as presented in Table 2. The morphology of the colony and the shape of conidium were shown in Figure 2.

\section{The observation of diseases in the shallot field}

Based on the field observations, the symptoms of Moler disease were discovered in all locations. Latifah et al. (2011) showed that pathogens can be carried out by the seeds or seedlings of shallots. This will lead to variations in the first symptoms and the incubation period of Moller disease on shallot plants. Nugroho et al. (2011) showed that the use of different shallot varieties caused the different intensity of the diseases. Meanwhile, the symptoms of Anthracnose were discovered in the six locations only (Table 3). The percentage of infected plants is presented in Table 4.

The area distribution of shallots in South Kalimantan was presented in Figure 3. The Moller disease distribution on shallots plant in South Kalimantan was shown in Figure 4.

Based on the observation of the disease distribution area in South Kalimantan, Anthracnose was observed in several districts. The data were collected according to the symptom estimation on the shallots after the isolation and identification stages. Anthracnose disease was discovered at several districts in South Kalimantan namely Balangan, Kotabaru, Tabalong, Tanah Laut, and Tapin, each with a different percentage of infected area. However, Anthracnose was not observed in Banjarbaru (Table 5). Anthracnose attacking shallots in Tabalong District was as many as $26 \%$ of the total infected area. This was the largest attack among other districts. Meanwhile, no Anthracnose disease attack was observed in Banjarbaru city. The data of Anthracnose disease in South Kalimantan can be seen in Figure 5. 


\section{The environmental effect towards the pathogen} reproduction

The soil $\mathrm{pH}$ range of six shallot cultivation districts in South Kalimantan was 5.79-7.55, with the characteristics of more acidic until more basic (Table 6). The rainfall, humidity, and temperature from November 2017 until March 2018 in South Kalimantan were also measured. The rainfall ranged from 86 to 545 millimeters, the humidity was between $84.2 \%-88.2 \%$, and the temperature was between $26.1^{\circ}-28.4^{\circ} \mathrm{C}$.

Fusarium sp. and Anthracnose in shallots are very dependent on environmental conditions, i.e., soil $\mathrm{pH}$, soil temperature, humidity, and nutrients. Conditions in the field can be very supportive of the growth of these pathogens. This is consistent with the statements of Agrios (1996) and Sastrahidayat (2011), which stated the development of pathogens increases with high temperatures and low soil $\mathrm{pH}$. At a temperature of $18^{\circ} \mathrm{C}$, there is a little infection in plants, in temperatures, $25-28^{\circ} \mathrm{C}$ pathogens will become malignant while at a temperature of $38^{\circ} \mathrm{C}$ the pathogen will die. At a soil temperature of $25-30^{\circ} \mathrm{C}$ the spores will germinate, so that the attack rate will increase due to increased softening of the root plants, which causes the wound to become easily injured to facilitate pathogens in the healing process in the host plant. While at lower temperatures the germination process will be hampered.

Table 3. The disease symptom observation of shallots cultivated in South Kalimantan, Indonesia

\begin{tabular}{|c|c|c|c|c|c|c|c|c|}
\hline \multirow[b]{2}{*}{ District/City } & \multirow{2}{*}{ Village } & \multirow{2}{*}{ Varieties } & \multirow{2}{*}{$\begin{array}{c}\text { Cultivation } \\
\text { Area }\left(\mathbf{m}^{2}\right)\end{array}$} & \multirow{2}{*}{$\begin{array}{c}\text { Total } \\
\text { cultivation } \\
\text { area }\left(\mathbf{m}^{2}\right)\end{array}$} & \multicolumn{2}{|c|}{ Symptoms } & \multicolumn{2}{|c|}{ Infected area $\left(\mathrm{m}^{2}\right)$} \\
\hline & & & & & Moller & Anthracnose & Moller & Anthracnose \\
\hline \multirow[t]{2}{*}{ Tabalong } & Jaro Bawah & Super Philips & 10000 & 20000 & + & + & 3468 & 5202 \\
\hline & Jaro Atas & Super philips & 10000 & & + & - & 2890 & - \\
\hline Balangan & Batu Mandi & Bima brebes & 289 & 289 & + & + & 86.7 & 28.9 \\
\hline \multirow[t]{2}{*}{ Tanah Laut } & Ambungan & Bima brebes & 2312 & 3757 & + & + & 867 & 144.5 \\
\hline & Ujung Batu & Bima brebes & 1445 & & + & + & 578 & 289 \\
\hline Kotabaru & Sehapi & Bima brebes & 10000 & 10000 & + & + & 2312 & 1445 \\
\hline \multirow[t]{2}{*}{ Tapin } & Asam Rendah & Batu Ijo & 10000 & 20000 & + & + & 5202 & 2890 \\
\hline & Harapan masa & Bima brebes & 10000 & & + & - & 1156 & - \\
\hline Banjarbaru & Loktabat & Bima brebes & 289 & 289 & + & - & 86.7 & - \\
\hline
\end{tabular}

Note: +: present, -: absent

Table 4. The distribution of Moller disease in South Kalimantan, Indonesia

\begin{tabular}{llcccc}
\hline District/City & Village & $\begin{array}{c}\text { Plant area } \\
\left(\mathbf{m}^{\mathbf{2}}\right)\end{array}$ & $\begin{array}{c}\text { Infected area } \\
\left(\mathbf{m}^{\mathbf{2}}\right)\end{array}$ & $\begin{array}{c}\text { Total infected area } \\
\left(\mathbf{m}^{\mathbf{2}}\right)\end{array}$ & Percentage of attack $(\boldsymbol{\%})$ \\
\hline Balangan & Batu Mandi & 289 & 86.7 & 86.7 & 30 \\
Banjarbaru & Loktabat & 289 & 86.7 & 86.7 & 30 \\
Kotabaru & Sehapi & 10000 & 2312 & 2312 & 23.1 \\
Tabalong & Jaro Atas & 20000 & 2890 & 6358 & 31.8 \\
& Jaro Bawah & & 3468 & 1445 & 38.5 \\
Tanah Laut & Ambungan & 3757 & 867 & & 31.8 \\
& Ujung Batu & & 578 & 6358 & \\
& Asam Randah & 20000 & 5202 & & \\
& Harapan Masa & & 1156 & & \\
\hline
\end{tabular}

Table 5. The distribution of Anthracnose disease attack in South Kalimantan, Indonesia

\begin{tabular}{llcccc}
\hline District/city & Village & $\begin{array}{c}\text { Cultivation } \\
\mathbf{a r e a}\left(\mathbf{m}^{\mathbf{2}}\right)\end{array}$ & $\begin{array}{c}\text { Infected area } \\
\left(\mathbf{m}^{\mathbf{2}}\right)\end{array}$ & $\begin{array}{c}\text { Total infected area } \\
\left(\mathbf{m}^{\mathbf{2}}\right)\end{array}$ & $\begin{array}{c}\text { Percentage of attack } \\
(\boldsymbol{\%})\end{array}$ \\
\hline Balangan & Batu Mandi & 289 & 28.9 & 28.9 & 10 \\
Banjarbaru & Loktabat & 289 & 0 & 0 & 0 \\
Kotabaru & Sehapi & 10000 & 1445 & 1445 & 14.4 \\
Tabalong & Jaro Atas & 20000 & 0 & 5202 & 26 \\
& Jaro Bawah & & 5202 & & \\
Tanah Laut & Ambungan & 3757 & 144.5 & 433.5 & 11.5 \\
Tapin & Ujung Batu & & 289 & & \\
& Asam Randah & 20000 & 2890 & 2890 & 14.4 \\
& Harapan Masa & & 0 & & \\
\hline
\end{tabular}




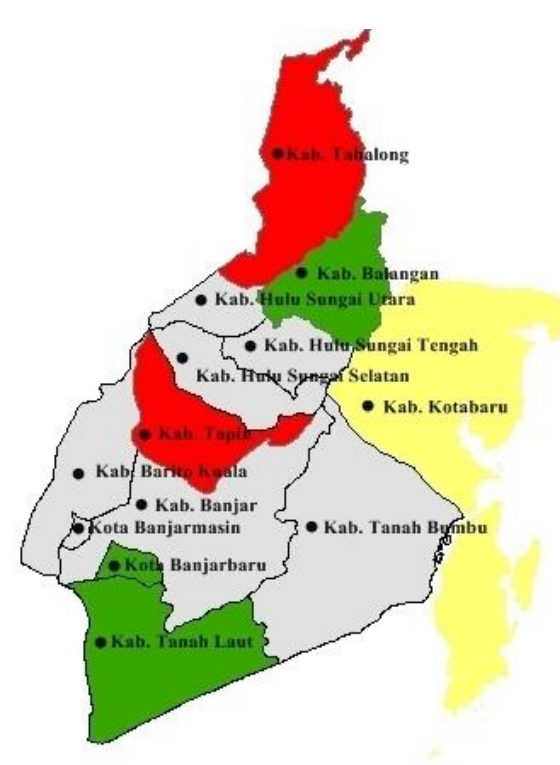
Large Area
$\square$ No Shallot Plant $289 \mathrm{~m}^{2}-7.225 \mathrm{~m}^{2}$ $7.514 \mathrm{~m}^{2}-14.450 \mathrm{~m}^{2}$ $\square 14.793 \mathrm{~m}^{2}-21.675 \mathrm{~m}^{2}$

Figure 3. Map of area distribution of shallots in South Kalimantan, Indonesia

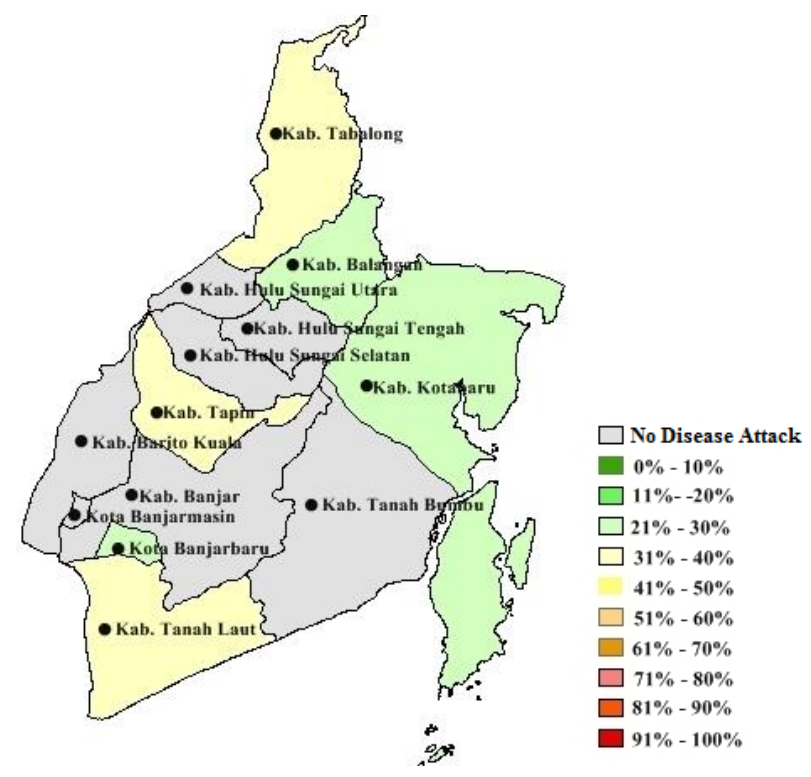

Figure 4. The map of Moller disease distribution of shallots in South Kalimantan, Indonesia

Table 6. The soil pH on shallots in South Kalimantan, Indonesia

\begin{tabular}{llll}
\hline District/City & Village & pH & Indication \\
\hline Tabalong & Jaro Bawah & 5.79 & More acidic \\
& Jaro Atas & 7.20 & More basic \\
Balangan & Batu Mandi & 6.48 & Neutral \\
Tanah Laut & Ambungan & 7.55 & More basic \\
& Ujung Batu & 6.14 & Neutral \\
Kotabaru & Sehapi & 5.96 & More acidic \\
Tapin & Asam Rendah & 6.67 & Neutral \\
& Harapan masa & 6.26 & Neutral \\
Banjarbaru & Loktabat & 6.17 & Neutral \\
\hline
\end{tabular}

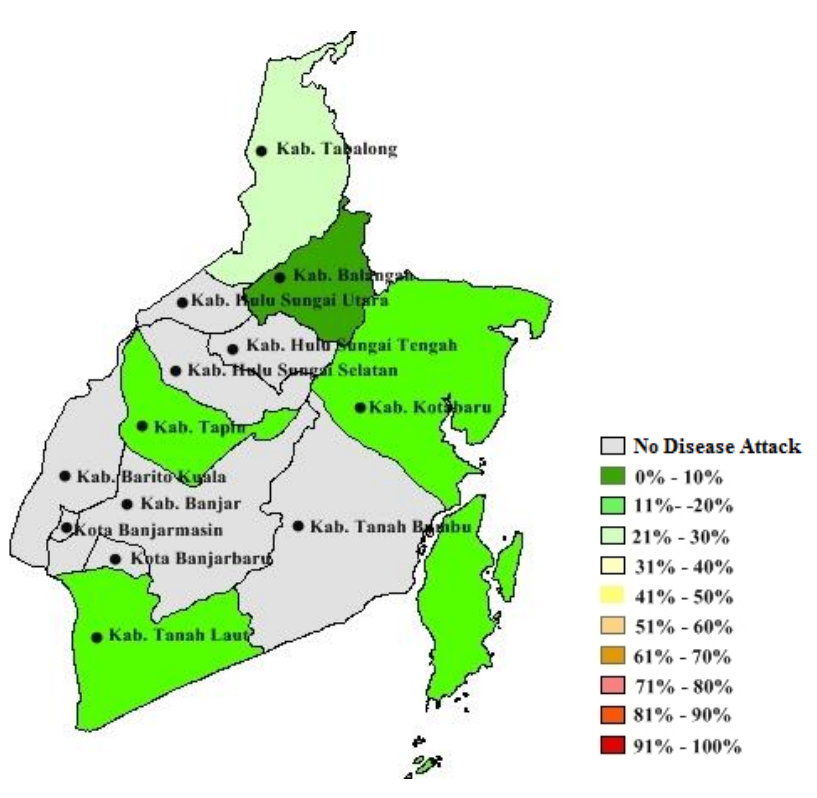

Figure 5. The map of Anthracnose disease distribution on shallots plant in South Kalimantan, Indonesia

\section{The Koch Postulate test result}

The Koch Postulate test was conducted by reinoculating the isolate, from an isolated infected plant in the field and from the pure culture. The result of inoculation on healthy plants is seen in Figure 6. The result of inoculation with the second isolate suspected due to Anthracnose is shown in Figure 7.

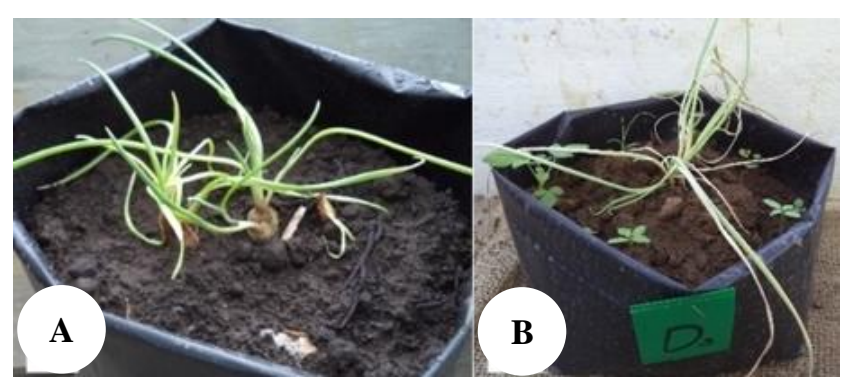

Figure 6. Symptoms resulted from inoculation with the isolate of Fusarium oxysporum on shallots. A. Initial symptoms of attack; B. Advanced symptoms of Moler disease

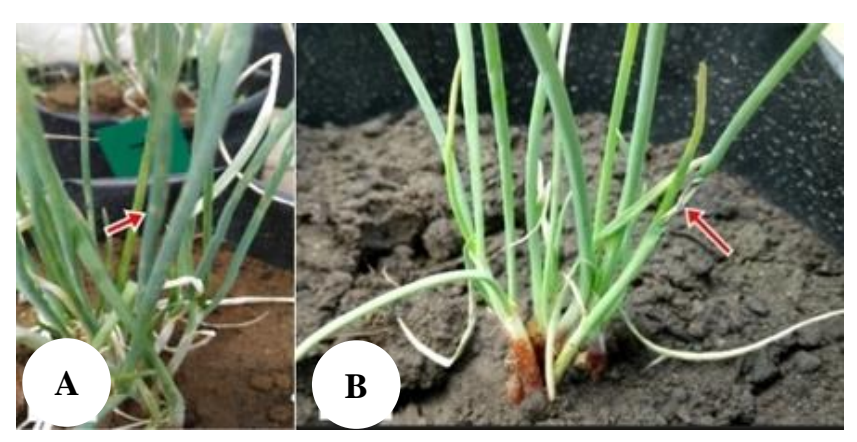

Figure 7. Symptoms of sick plant inoculated with the isolate of Colletotrichum sp. A. Initial symptoms spots appeared; B. Advanced symptoms, spots become larger, and the leaf twisted 
Figures 6 and 7 showed that the symptom of $F$. oxysporum and anthracnose on shallots. Figure 6.A showed the early symptoms of Fusarium and Figure 6.B showed the late symptoms. Whereas Figure $7 \mathrm{a}$ showed the early symptoms of Anthracnose caused by Colletotrichum sp and Figure $7 \mathrm{~b}$ showed the late symptoms of anthracnose diseases.

\section{Discussion}

According to the results of the field observations at six districts in South Kalimantan, there were two types of diseases attacking the shallots: Moler disease and Anthracnose disease. Moler disease was caused by Fusarium oxysporum fungi. The characteristics of this disease are started by shriveling at the tip of the leaf and pervading to its base (Samadi and Cahyono 2005). This type of fungi spreads through seed bulbs, air, soil, and water. If the contagion is throughout the seed bulbs, the symptoms appear about 7 until 14 days after panting. However, the symptoms appear 14 days after planting if the contagion is throughout the soil, air, and water (Suryanto 2010). According to Semangun (2000), the first symptom of Moler disease on shallots is the leaf turned yellow starting from its base, then pervading to the middle part until the whole plant withered and dried. The leaves of shallots infected with Moler disease would most likely be twisted. On the other hand, Anthracnose disease, according to Suhardi (1991) and Suhendro et al. (2001) would cause the leaves to have brown spots which can make the leaf break and fall. However, the bulb part would turn dark green and black. Subsequently, the leaf would become twisted (rolled). If the root is infected, the leaf cannot grow up like usual. The infected bulbs cause the plants to decay. According to Hadiwiyono (2004); Suhardi and Hadisutrisno (1994); and Suhardi et al. (1994; 2000) and Semangun (2007), Moler disease caused by Fusarium can attack all types of onions. This fungus can infect shallots in all growth stages of the plant, and this was supported by Abawi and Lorbeer (1972). On the other hand, Anthracnose disease can be unbearable for some shallots' clones, even though Sumenep cultivation was considered tolerant to this disease.

Based on Agrios (1996) and Semangun (1996), the fungi had a colony that was colorless until cream or light yellow and could be discovered in light red or purple with insulating mycelium. The microconidia are round-shaped, ovoid kidney, and lancet, meanwhile its macroconidia is crescent-shaped with many septa. In the PDA medium, fungi Colletotrichum sp. can grow well at room temperature. Liu et al. (2016) and Semangun (2007) reported that the fungi colony had pale grey blackish color, oval-shaped conidia, uninsulated, hyaline with the blunt end.

The result of soil $\mathrm{pH}$ analysis showed that the soil taken from six districts in South Kalimantan had $\mathrm{pH}$ ranging from 5.79-7.55 with characteristics of more acidic and more basic. According to Tjahjadi (1989) and Sastrahidayat (1989), these fungi could live with temperatures ranging from $10^{\circ} \mathrm{C}-24^{\circ} \mathrm{C}$ and more acidic soil with $\mathrm{pH}$ ranging from 4.5-6.0, and the wet soil conditions caused Fusarium sp. fungi to grow fast. However, Colletotrichum sp. fungi according to Yulianty (2006) need a pH of 5 to grow well and quickly.

\section{The distribution area of shallot cultivation in South Kalimantan}

The survey of shallot cultivation in South Kalimantan resulted in the area distribution map of shallots in several districts in South Kalimantan. This showed both the different extensive planting methods and that half of the districts did not cultivate shallots. The distribution of shallots in South Kalimantan is presented in Figure 1. When the survey was conducted, some farmers were not planting the shallots. The plant areas changed from time to time and varied for each district or city.

The diverse areas of shallots were in Balangan, Banjarbaru, Kotabaru, Tabalong, Tanah Laut, and Tapin districts. The rest of the districts did not plant shallots at that time. The rainfall conditions when the survey was conducted probably affected the shallot planting activity. The survey was conducted from November 2017 to March 2018 when the rainfall level was high, and some farmers were not planting the shallots. The largest areas of shallot cultivation were in Tabalong and Tapin with a total plant area of $20.000 \mathrm{~m}^{2}$; and the smallest areas were in Balangan and Banjarbaru about $289 \mathrm{~m}^{2}$.

The high level of rainfall would inhibit shallot growth and increase the chance of disease infection. Rahayu (2009) reported that shallots are well cultivated in the dry season. It can be seen from the length of plants, the width of leaves, the rate of plant growth, the diameter of seed bulbs, the weight of dry seeds (under the sun) of each clump, and the productivity of plants per hectare that these were slower in the peak of rainy season. This case was one of the reasons for the farmers refusing to plant shallots in this period or even speed up the harvest. This was in accordance with what Purba (2009) stated that the decrease of shallot production in the rainy season was because of the disease attack and the growth disruption was due to the leaves that were hard to photosynthesize.

The areas of shallots surveyed also had different altitudes. The areas of shallots in Asam Randah village in the district of Tapin had an uphill shape and uneven land. The same condition was in the planting area in Sehapi village located on the hillside of highland and uneven land in the district of Kotabaru. The differences in altitude made the growth rate of shallots vary from place to place. The high altitudes had a lower temperature, thus affecting the shallots growth rate and production. The altitude was the main factor that change the diversity of heat, the average temperatures decreased along with the increase of the altitude approximately $0.6^{\circ} \mathrm{C}$ every $100 \mathrm{~m}$ (Anshari et al. 2011).

The varieties of shallots planted in the surveyed locations were mostly Bima Brebes variety. Only three locations that used other varieties, including Super Philips variety used in Jaro Atas and Jaro Bawah village and Batu Ijo variety, was used in Asam Randah village, Tapin district. The uSuper Philips variety was the most used variety since this one is more tolerant to several diseases. 
This was a similar reason for Asam Randah village farmers in Tapin in using Batu Ijo variety in shallots cultivation.

\section{The distribution of Moler disease on shallots in South Kalimantan}

The field survey showed that Moler disease symptoms were discovered in some districts in the shallot cultivated areas in South Kalimantan. Moler disease is one of the major diseases attacking shallots in South Kalimantan. The data was supported by Safitri et al. (2018) that the Moler diseases were identified as one of two major diseases that attacked shallots in South Kalimantan.

The percentage of Moler disease attacks ranges from 23.1-38.5\%. The largest area attacked by Moler disease according to its symptoms was in Tanah Laut District, where the total of the infected area reached $38.5 \%$. On the other hand, the lowest attack was recorded in Kotabaru with the attack percentage being only $23.1 \%$.

The distribution of Moler disease in South Kalimantan spread to whole districts with the largest attack being in the district of Tabalong with the total planting areas of 6358 $\mathrm{m}^{2}$. The lowest attack was in Balangan District and Banjarbaru city with the total plant areas $86.7 \mathrm{~m}^{2}$ However, according to the percentage of attacks, Tanah Laut District was the largest area attacked by this disease with a total percentage of $38.5 \%$ from the total cultivated area. Tapin district was the lowest area attacked by the disease with a percentage of only $23.1 \%$ of the total cultivated area in the whole district of Kotabaru. The environmental condition is one of the factors determining the Moler disease development. The significant weather change caused this disease to increase. Soil nutrient leaching caused by the runoff made the nutrient deficiency and increased disease growth. Wiyono (2007) reported that climate change, such as the increase of temperature, increased the disease condition. Besides, the low organic content in the soil also contributed to the increasing disease severity.

Sastrahidayat (1992) stated that the growth of Moler disease was affected by the condition of the environment such as soil pH level, soil temperature, humidity, and soil nutrient. $F$. oxysporum fungi could grow in low soil $\mathrm{pH}$ levels and temperature between $18^{\circ} \mathrm{C}$ and $38^{\circ} \mathrm{C}$. High humidity would affect the growth of host plant which turned into succulent. Therefore, the immune system of the plant to the pathogens would decrease (Supriyadi et al. 2013). The low soil $\mathrm{pH}$ level was good for Moler disease but was not good to plant because it would make the plant sensitive to disease infection.

\section{The distribution of Anthracnose disease on shallots in South Kalimantan}

The field survey showed that Anthracnose disease had attacked cultivated shallots in several districts in South Kalimantan. The same indication was observed by Safitri et al. (2018) that had successfully isolated and identified the Anthracnose diseases in the shallot cultivation areas. Anthracnose was found in several districts in South Kalimantan such as Balangan, Kotabaru, Tabalong, Tanah Laut, and Tapin with different intensities of attack.
However, there was no attack in Banjarbaru city. Anthracnose disease attacked shallots in Tabalong with a percentage of $26 \%$. This was the largest attack among other districts.

The largest infected areas of Anthracnose disease were in Tabalong and Tapin. It reached $26 \%$ of the whole planting area in both districts. The smallest infected area of Anthracnose disease was Balangan, which was only $10 \%$ of total planting area.

The high intensity of rainfall when the research was conducted was one of the factors that can influence disease growth. Humidity will increase if the temperature is low due to high rainfall. High levels of moisture make pathogens grow faster. Semangun (2011) reported that the growth rate of Anthracnose disease will be faster when the humidity is high, or higher than $80 \%$. The thickness of the onion tuber epidermis affects the intensity of the attack of C. gloeosporioides. The thicker the epidermis layer, the more resistant to the attack of $C$. gloeosporioides (Marlitasari et al. 2016).

\section{REFERENCES}

Adiyoga W, Moekasan TK, Uhan TS, Suenaryo E, Hendarsih. 2000. Present status of pest and disease management on food and vegetable crops and its future development. PEI (Perhimpunan Entomologi Indonesia), Surakarta and PT. PCI, Jakarta.

Agrios GN. 1996. Plant Pathology 4th ed. Academic Press, New York.

Alexopoulos CJ, Mims CW, Blackwell M. 1996. Introductory Mycology. John Wiley \& Sons, Inc. New York.

Anshari, Tohari M, Bambang HS, Endang S. 2011. Growth, yield, and quality of shallot bulbs on soil moisture and altitude of different places. J Agrivigor 10 (2): 128-138. [Indonesian]

Aziza NL. 2016. Application Analysis of Fusarium spp. Potassium Fertilizer and Planting Patterns Against the incidence of Molecular Disease and Growth and Yield of Shallots. [Thesis]. Faculty of Agriculture, University of Lambung Mangkurat. Banjarbaru. [Indonesian]

Bambang HI, Khusnul M. 2014. Effectiveness of resistance and biopesticide induction on Cercospora and Anthracnose leaves in chili (Capsicum annuum L.). Planta Tropika J Agro Sci 2 (2): 106-114. [Indonesian]

Barnett HL. 1960. Illustrated Genera Of Imperfect Fungi. 2nd ed. Burgess Publishing Company, USA.

Booth C. 1971. The Genus Fusarium. Commonwealth Mycological Institute, Key Surrey, UK.

Dinas Tanaman Pangan dan Hortikultura Provinsi Kalimantan Selatan. 2017. Annual Report on Horticulture Crop Productivity in South Kalimantan. South Kalimantan Prov. Govt., Banjarbaru. [Indonesian]

Everts KL, Lacy ML. 1990. Influence of environmental on conidial concentration of Alternaria porri in air and on purple blotch incidence on onion. Phytopathology 80 (12): 1387-1391.

Glande DR, Simon S. 2019. Effect of intercropping on purple blotch (Alternaria porri) of onion (Allium cepa L.). Intl J Curr Microbiol App Sci 8 (2): 1105-1111.

Latifah A, Kustantinah, Soesanto L. 2011. Utilization of several Trichoderma harzianum isolates as biological control agents for Fusarium wilt on shallots in planta. J Eugenia 2 (17): 86-94. [Indonesian]

Liu F, Tang G, Zheng X, Li Y, Sun X, Qi X, Zhou Y, Xu J, Chen H, Chang X, Zhang S, Gong G. 2016. Molecular and Phenotypic Characterization of Colletotrichum Species Associated with Anthracnose Disease in Peppers from Sichuan Province, China. Scientific Reports, PRC.

Marlitasari E, Sulistyowati L, Kusuma RR. 2016. Relationship between leaf epidermal layer thickness and Alternaria porri fungal infection caused purple spot disease in four shallot varieties. J HPT 4 (1): 8-16. [Indonesian] 
Nugroho B, Astriani D, dan Mildaryani W. 2011. The virulence variation of Fusarium oxysporum. ssp. cepae isolates on several shallot varieties. J Agrin 1 (15): 8-17. [Indonesian]

Purba R, Yati A. 2013. The shallots Technology Package Outside the Planting Season in Banten Pandeglang. Assessment of Banten Agricultural Technology (15) 10: 105-113. [Indonesian]

Rahayu YS. 2009. Effect of planting time to the growth and yield of several shallot varieties (Allium ascalonicum $\mathrm{L}$.). [Indonesian]

Safitri YA, Salamiah, Samharinto. 2018. Exploration and Identification of Shallot Plant Disease in South Kalimantan. [Skription]. Faculty of Agriculture. Lambung Mangkurat University. Banjarbaru. [Indonesian]

Sastrahidayat IR. 1989. Plant Diseases Science. Usaha Nasional. Surabaya. [Indonesian]

Sastrahidayat IR. 2011. Fitopatology (Plant Diseases Science). Brawijaya University Press. Malang. [Indonesian]

Sastrahidayat. 1992. Plant Tomatoes. Penebar Swadaya. Jakarta [Indonesian]
Semangun H. 2001. Introduction to Plant Disease Science. Gadjah Mada University Press. Yogyakarta. [Indonesian]

Semangun H. 2011. Horticultural Plant Diseases in Indonesia. Gadjah Mada Univesity Press. Yogyakarta. [Indonesian]

Supriyadi A, Ika R, Syamsudin D. 2013. Disease in shallots plants cultivated vertically in Sidoarjo. J HPT 3 (1): 27-40. [Indonesian]

Tjahjadi N. 1989. Pests and Plant Diseases. Kanisius. Yogyakarta. [Indonesian]

Tuite J. 1969. Plant Pathological Methods: Fungi and Bacteria. Burgess Publ. Co., Minneapolis, Minnesota.

Udiarto BK, Wiwin S, Euis S. 2005. Introduction of Shallots and Diseases and their control. PTT Bawang Merah no. 2. Vegetable Crops Research Institute, Bandung. [Indonesian]

Wiyono S. 2007. Climate Change and Explosion of Pests and Plant Diseases. Department of Plant Protection, Faculty of Agriculture, Institut Pertanian Bogor, Bogor. [Indonesian]

Yulianty. 2006. Effect of $\mathrm{pH}$ on fungal growth of Colletotrichum capsici causes of anthracnose in chili (Capsicum annum L.) plants from Lampung. http: //www.thechileman.org/guide.disease. [Indonesian] 